Energy Conversion and Management, Volume 171, September 2018, Pages 1237-1245

DOI: 10.1016/j.enconman.2018.06.064

\title{
Thermal performance of different integration schemes for a solar tower aided coal-fired
}

\section{power system}

Chao Li ${ }^{\mathrm{a}, \mathrm{b}}$, Rongrong Zhai ${ }^{\mathrm{a}, *}$, Yongping Yang ${ }^{\mathrm{a}}$, Kumar Patchigolla ${ }^{\mathrm{b}}$, John E. Oakey ${ }^{\mathrm{b}}$

${ }^{a}$ School of Energy, Power and Mechanical Engineering, North China Electric Power University, Beijing 102206, China

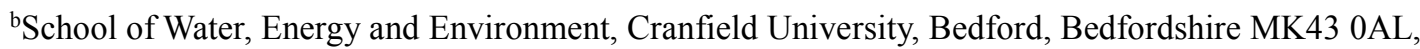
UK

*Corresponding author: Rongrong Zhai

E-mail:zhairongrong01@163.com

Tel.:+86-10-61772284; Fax: +86-10-61772284

Abstract: A Solar Tower Aided Coal-fired Power (STACP) system utilizes a solar tower coupled to a conventional coal-fired power system to reduce pollutants, greenhouse gas emissions and the investment of solar energy facilities. This paper examines three different schemes for integrating solar energy into a conventional boiler. For each scheme, an energy and exergy analysis of a $600 \mathrm{MW}_{\mathrm{e}}$ supercritical coalfired power system is combined with $53 \mathrm{MW}_{\text {th }}$ of solar energy in both a fuel saving mode and a power boosting mode. The results show that, for all these integration schemes, the boiler's efficiency and system's efficiency are reduced. However, the standard coal consumption rate is lower in comparison to conventional power plants and the standard coal consumption rate in the fuel saving mode is lower than in the power boosting mode for all three schemes. Comprehensively considering both the standard coal consumption rate and efficiency, the scheme that uses solar energy to heat superheated steam and subcooled feed-water is the best integration option. Compared with a coal-fired only system, the saved standard coal consumption rate of the above mentioned scheme in fuel saving mode and power boosting 
mode can reach up to $11.15 \mathrm{~g} / \mathrm{kWh}$ and $11.11 \mathrm{~g} / \mathrm{kWh}$, respectively. Exergy analysis shows, for STACP system, exergy losses of boiler and solar field contribute over $88 \%$ of whole system's exergy loss.

Keywords: solar tower power system, coal-fired power system, fuel saving mode, power boosting mode, exergy analysis

\section{Introduction}

Air pollution and global warming have been posing a serious threat to human health and the environment, which is mainly caused by the use of fossil fuel. In China, over 70\% of the electrical demand is met by coal-fired power generation stations[1,2], which contributes a large proportion of greenhouse gas and pollution emissions. In this matter, the Chinese government has taken effective emergency measures in order to address these problems. One way to deal with this situation is to exploit renewable energy to replace coal-fired power generation. Of all the renewable energy, concentrated solar power, which can be built in large scale, is a promising technology that can meet the power demand for China. However, at present, the solar-only thermal power plant still cannot be built at such a large scale because the cost is extremely high and the annual global efficiency is low. Because the steam cycle of solar thermal power plant is similar to that of a coal-fired power plant, integrating solar thermal energy into coal-fired power plant, also known as solar aided coal-fired power (SACP) system, is not only to reduce greenhouse gas emissions but also to reduce the investment in solar energy facilities.

A SACP system was first studied by Zoschak and Wu in 1975[3]. Seven possible methods of integrating solar energy to a coal-fired power system were proposed and analyzed. Results show that combing solar energy with the evaporation and superheating is the most preferred method due to the high utilization of solar energy, and using solar energy to preheat feed-water is also a favorable method. However, in the most recent studies related to SACP systems, solar energy is used to preheat feed- 
water[4-8], and the focus is mainly on evaluating different integration schemes, operation modes and its thermal and economic performances. For the system integration aspect, Hu et al. used solar energy to replace the extracted steam to heat the feed-water. Results showed that the higher the temperature aided heat source is, the more beneficial the system can be[9]. Yang et al. considered a $200 \mathrm{MW}_{\mathrm{e}}$ coal-fired unit as an example and explored four different integration schemes in fuel saving mode and power boosting mode. In power boosting mode, the system can generate additional power while consuming the same amount of fuel[10]. In terms of operation modes, Qin et al. proposed four possible SACP system configurations and three operation strategies. Therefore, an SACP system with twelve potential "configuration-operation" combinations was investigated [11]. They studied the impact of the two different operation strategies for non-displaced feed-water heaters on the plant's performance. The results indicated that a plant with a constant temperature strategy is generally better than one operating with a constant mass flow rate strategy[12]. Recently, they proposed a mixed operation mode, in which the SACP system can be operated at a series of time intervals and, in each time interval, the system operated in either power boosting or fuel saving mode. The results showed that the annual profitability of such a mixed operation mode could be up to $12.1 \%$ higher than that of a single operation mode[13]. In the area of thermal performance of a SACP system, Hou et al. investigated the performance of a SACP system at the design point under various load conditions and the performance in fuel saving mode under different solar radiation conditions $[14,15]$. Huang et al. discussed the influences of power station capacities and sizes of solar field on the performance of the SACP system[16]. Adibhatla et al. conducted exergy and thermo-economic analyses on a $500 \mathrm{MW}_{\mathrm{e}} \mathrm{SACP}$ plant. The exergy analysis showed that the solar field and boiler have the two highest exergy destruction ratios (78.90\% and 56.52\%) and the thermo-economic analysis showed that the product cost rate of the generator was $19.1 \mathrm{USD} / \mathrm{kJ}[17]$. Li et al. studied the 
performance of the SACP system based on the all-condition mechanism model of the SACP system[1]. Hong et al. demonstrated the performance behaviors of a $330 \mathrm{MW}_{\mathrm{e}} \mathrm{SACP}$ plant under off-design conditions by applying the derived expressions of the conversion of solar energy into power[18]. From the economic aspect, $\mathrm{Wu}$ et al. explored the annual economic performance of the SACP system under different tracking modes, aperture areas, and storage capacities[19]. Adibhatla et al. used an energy, exergy, economic and environmental (4E) method to analyze the SACP system[20]. Wang et al. optimized the solar multiple for a SACP system from the technical and economic aspects, the results showed that the efficiencies in the region of $13-20 \%$ can be achieved and the reduction in the levelized cost of electricity was in the region of $0.7-1.1 \quad ¥ / \mathrm{kWh}$ [21]. Various ways of evaluating SACP systems have been used. Zhai et al. evaluated the SACP system using a life cycle assessment method[22]. Peng et al. evaluated the system using an energy-utilization diagram methodology[23]. Zhai et al. proposed an evaluation method named solar contribution evaluation method, based on the second law of thermodynamics and exergy balance, and distinguished the difference of exergy efficiency between solar and coal in the SACP system[24]. Hou et al. proposed a new evaluation method of solar contribution in a SACP system based on exergy analysis[25].

In combining solar energy with the evaporation and superheating areas, due to the high temperature of steam/water in the boiler, solar tower technology is an ideal option to consider. Zhang et al. proposed two schemes of the solar tower aided coal-fired power (STACP) system, where the standard coal consumption rate could be reduced by more than $17 \mathrm{~g} / \mathrm{kWh}$ and a flue gas bypass was introduced to avoid high thermal stress across its support frame[26]. In their following work, the annual performance of the two schemes with thermal energy storage, using a single-tank thermocline technology, were investigated. Results showed that the solar power efficiency was around $16-20 \%[27]$. Zhu et al. applied exergy and 
advanced exergetic analysis methods to a STACP system and found maximum exergy loss occurs in the boiler (53.5\%), followed by the solar field (26\%)[28]. Then, they studied the annual performance of a STACP system and found that the annual average coal consumption rate of STACP system is $27.3 \mathrm{~g} / \mathrm{kWh}$ lower than that of coal-fired power system and the annual average $\mathrm{CO}_{2}$ emission rate of STACP system is reduced by $10.1 \%$ compared with that of coal-fired power system[29].

There has been much researches regarding solar energy integration to preheat feed-water, and limited efforts have been made on integrating solar energy with evaporation and super-heating. Because of the temperatures involved and the need to improve the cycle efficiency, the temperatures available from a solar tower system are more suitable to utilize with evaporators and super-heaters in a conventional boiler system. In this paper, three different schemes for integrating solar energy into a boiler are proposed under either a fuel saving mode or a power boosting mode with same solar energy input. In scheme 1 , solar energy is used to heat part of the superheat steam. In scheme 2, solar energy is used to heat part of the feed-water and superheat steam. In scheme 3, solar energy is used to heat part of the feedwater, superheat and reheat steam. Both fuel saving and power boosting modes share the same system configuration, and the only difference between these two operation modes is the coal consumption input. In the fuel saving mode the overall power output is kept constant, and coal input to the power system is reduced when solar energy is available. In the power boosting mode, additional power is produced, and coal input to the power system is constant when solar energy is available. A total of 6 cases are studied in this paper and the following abbreviations are used to refer to each: scheme 1 in fuel saving mode (FS1), scheme 1 in power boosting mode (PB1), scheme 2 in fuel saving mode (FS2), scheme 2 in power boosting mode (PB2), scheme 3 in fuel saving mode (FS3), and scheme 3 in power boosting mode (PB3). This study has three main novel features in comparison to our own studies [28]: (1) The boiler model is 
established in detail instead of treating it as a "black box". (2) The performances of the three different integration schemes under both fuel saving mode and power boosting mode are investigated and compared from both energy and exergy aspects. (3) Sankey diagrams are incorporated to analyze and compare the exergy performance between coal-fired power system, FS2 and PB2.

\section{System description}

2.1 Solar tower aided coal-fired power system

Fig. 1 shows a schematic of the STACP system, which contains the solar field and the coal-fired power plant. The solar field is composed of many heliostats, a solar tower, a columnar receiver, and a heat exchanger. In the solar field, solar energy is reflected onto a receiver that is at the top of the tower by the heliostats. Molten salt passes through the receiver to absorb the solar energy and the thermal energy of the molten salt is then transferred to the steam/water cycle in separate heat exchangers. The molten salt used in this study is a mixture of $60 \mathrm{wt} \% \mathrm{NaNO}_{3}$ and $40 \mathrm{wt} \% \mathrm{KNO}_{3}$. The thermal properties of the molten salt are a function of temperature as follows[30]:

$$
\begin{aligned}
& \rho=2263.72-0.636 \mathrm{~T} \\
& c_{p}=1396.02+0.172 \mathrm{~T} \\
& \lambda=0.391+0.00019 \mathrm{~T}
\end{aligned}
$$

Where, $\rho$ is density of molten salt, $\mathrm{kg} / \mathrm{m}^{3} ; c_{p}$ is specific heat of molten salt at constant pressure, $\mathrm{J} /(\mathrm{kg}$ $\mathrm{K}) ; \lambda$ is thermal conductivity of molten salt, $\mathrm{W} /(\mathrm{m} \mathrm{K}) ; \mathrm{T}$ is the temperature of molten salt, $\mathrm{K}$.

A conventional $600 \mathrm{MW}_{\mathrm{e}}$ ultra-supercritical coal-fired power plant is considered in this paper and the thermal parameters of the main steam and reheat steam are 566/24.2 and 566/3.6 ( $\square / \mathrm{MPa})$, respectively. In the coal-fired power plant, the unsaturated feed-water from the condenser enters the boiler after going through the condensate pump, four low pressure heaters ( $\mathrm{H} 5, \mathrm{H} 6, \mathrm{H} 7$, and $\mathrm{H} 8$ ), a 
deaerator, feed-water pump and three high pressure heaters (H1, H2, and H3). Then the feed-water absorbs heat in the boiler and becomes superheat steam. The outlet superheat steam from the boiler is transported to the high pressure turbine (HP) to produce power. The steam from the HP goes into the boiler to be reheated in order to improve its work capacity. Then the reheat steam is transported to the intermediate pressure turbine (IP) and low pressure turbine (LP) to produce power. Finally exhaust steam is condensed in the condenser.

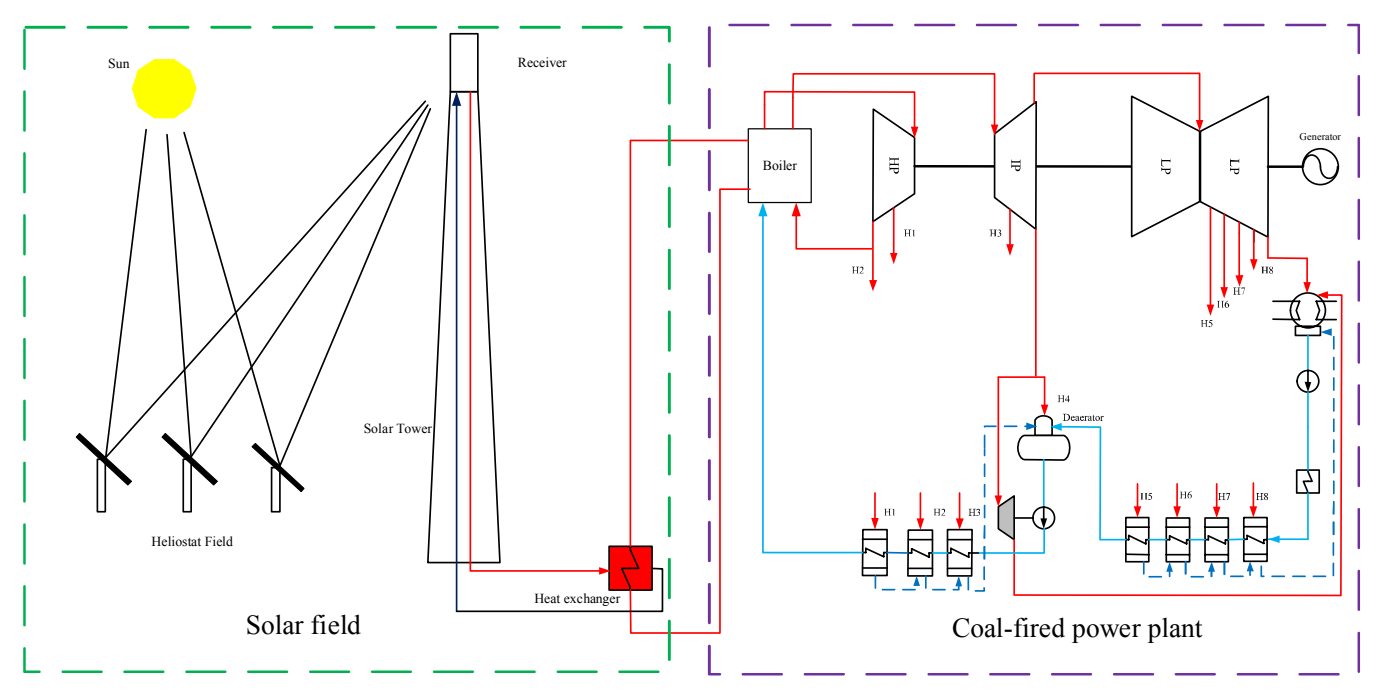

Fig.1 The diagram of solar tower aided coal-fired power system

2.2 Physical models of different integrating schemes

Fig. 2 shows main components for the three integrating schemes. Feed-water from the high pressure heaters first goes to the economizer (ECO), and then to the water wall from the bottom of the boiler. In this the feed-water partially turns into steam due to radiative heat absorption from the flame in the furnace. Then steam/water mixture enters to the steam separator (SEP), where the steam is separated and passes through the first platen super-heater (FPS), the second platen super-heater (SPS) and the final superheater (FS) to the HP. In order to maintain temperature of the main steam, there are two attemperators before the SPS and FS. The cold reheat steam from the HP passes through a low-temperature re-heater 
(LR) and a high-temperature re-heater (HR) to the IP.

In scheme 1, due to the instability of SEP and the complexity of the enclosure wall super-heater and the roof wall super-heater, part of steam is extracted from the inlet of the FPS. Then, the extracted steam from the boiler is transported to the Molten Salt Heat Exchanger (MSHE) to heat up to $566 \square$, because the temperature of the main steam is $566 \square$. Finally, the extracted steam is mixed with the superheat steam from the FS to form the main steam that is sent to HP. In scheme 1, only the superheating part of the boiler is integrated with the solar energy. In fact, it is the evaporation part of the boiler that makes up the largest proportion of thermal load. Therefore, in scheme 2, part of subcooled feed-water is extracted from the ECO instead and the extracted working fluid is mixed with the superheat steam after being heated in MSHE. Different from Scheme 1, the working fluid extracted in Scheme 2 is subcooled feedwater. Therefore, the heat exchanger must include both the evaporation and superheating parts. In scheme 3 , re-heaters in the boiler are taken into consideration, so the working fluid extracted is divided into two parts. The first part is the same as in scheme 2, the other part is that part of the reheat steam that is heated by the heat exchanger in the solar field instead of the LR and HR in the boiler. The inputs and outputs of these three schemes are represented as A, B and C in Fig. 2, respectively.

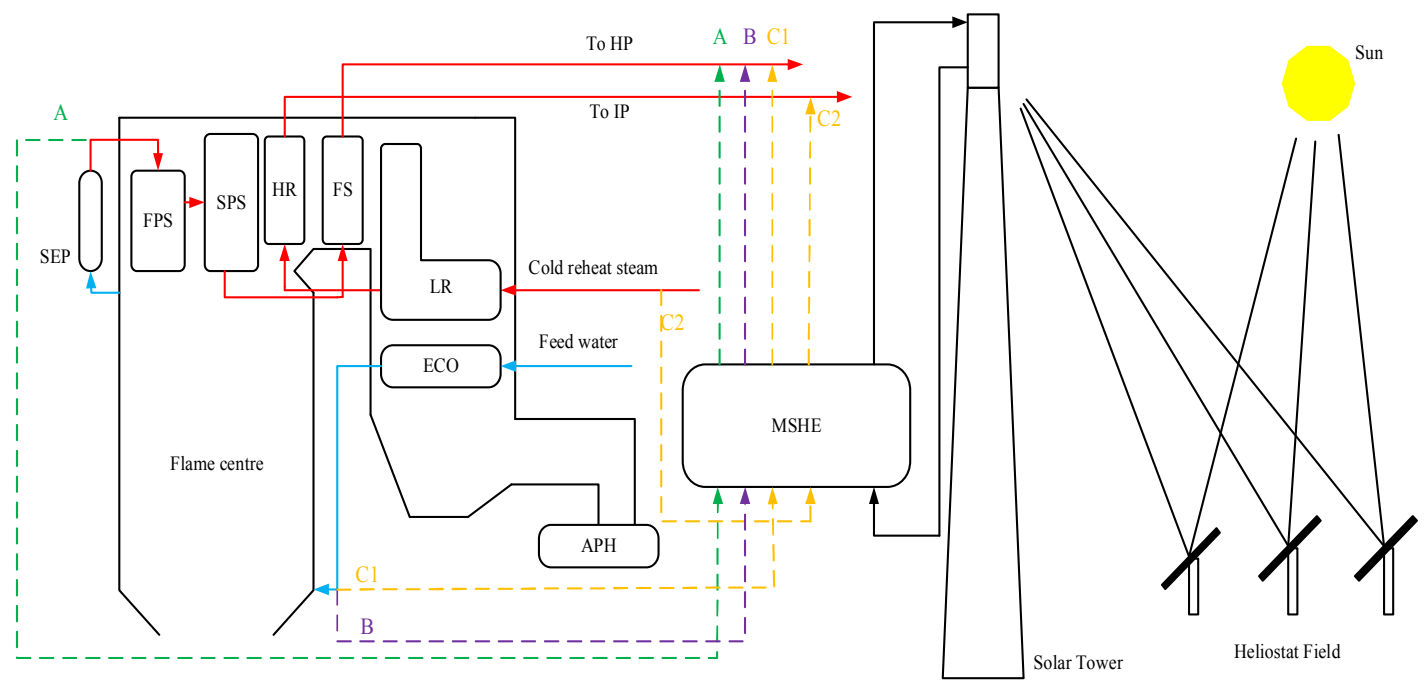


Fig.2 Physical models of different integrating schemes of the solar energy and boiler

Notes: FS1 and PB1: Steam is extracted from the inlet of the FPS and is sent back to HP (green line);

FS2 and PB2: Water is extracted from the outlet of the ECO and is sent back to HP (purple line); FS3

and PB3: Water is extracted from the outlet of the ECO and is sent back to HP. Reheat steam is

extracted from the inlet of the LR and is sent back to IP (orange line).

\section{Methodology}

\subsection{Energy and exergy analysis}

In this study, mass, energy and exergy balances are used to analyze the STACP system. The energy and exergy analysis of the whole STACP system can be carried out by combining the analysis of each subsystem. To simplify the calculations, some important assumptions in the analysis are considered:

(a) The system operates at a steady-state with a constant direct normal irradiance (DNI).

(b) Pressure drop and heat losses in pipelines are not considered.

(c) The ambient temperature is $25 \square$ and the ambient pressure is $1 \mathrm{~atm}$.

For certain equipment, the energy balance and exergy balance can be presented as follows:

$$
\begin{gathered}
\mathrm{E}_{\text {gain }}=\mathrm{E}_{\text {cost }}-\mathrm{E}_{\text {loss }} \\
\mathrm{Ex}_{\text {gain }}=\mathrm{Ex}_{\text {cost }}-\mathrm{Ex}_{\text {loss }}
\end{gathered}
$$

Where, $\mathrm{E}_{\text {gain }}$ is the obtained energy, $\mathrm{MW} ; \mathrm{E}_{\text {cost }}$ is the disbursed energy of an equipment, $\mathrm{MW}$; $\mathrm{E}_{\text {loss }}$ is the energy loss, $\mathrm{MW}$; $\mathrm{Ex}_{\text {gain }}$ is the obtained exergy, $\mathrm{MW} ; \mathrm{Ex}_{\text {cost }}$ is the disbursed exergy of an equipment, MW; $\mathrm{Ex}_{\text {loss }}$ is the exergy loss, MW.

The exergy at a specific state can be obtained by:

$$
\mathrm{Ex}=10^{-3} \mathrm{~m} \cdot \mathrm{ex}=10^{-3} \mathrm{~m}\left[\mathrm{~h}-\mathrm{h}_{0}-\mathrm{T}_{0}\left(\mathrm{~s}-\mathrm{s}_{0}\right)\right]
$$

Where, $\mathrm{m}$ is the mass flow rate of the fluid, $\mathrm{kg} / \mathrm{s}$; ex is the specific exergy, $\mathrm{kJ} / \mathrm{kg} ; \mathrm{h}$ and $\mathrm{h}_{0}$ are the specific 
enthalpy at a specific state and ambient state, $\mathrm{kJ} / \mathrm{kg} ; \mathrm{T}_{0}$ is the ambient temperature, $\mathrm{K} ; \mathrm{s}$ and $\mathrm{s}_{0}$ are the specific entropy at a specific state and ambient state, $\mathrm{kJ} /(\mathrm{kg} \mathrm{K})$.

\subsection{Model development}

\subsubsection{Heliostat model}

Heliostat field consists of many independently controlled heliostats, which can reflect the sun rays to the receiver at the top of the solar tower. The thermal energy reflected to the receiver can be calculated as:

$$
\mathrm{E}_{\text {hel }}=\mathrm{E}_{\mathrm{solar}} \cdot \eta_{\text {hel }}
$$

Where, $E_{\text {hel }}$ is the solar energy reflected by the heliostats, MW; $\eta_{\text {hel }}$ is the heliostat efficiency, which is set to $58.71 \%$ in this study[31]; $\mathrm{E}_{\text {solar }}$ is the solar energy falling on the heliostats, MW, and can be calculated by:

$$
\mathrm{E}_{\text {solar }}=\mathrm{A}_{\text {hel }} \cdot \mathrm{DNI} / 10^{6}
$$

Where, $A_{\text {hel }}$ is the total mirror area of the heliostat field, $\mathrm{m}^{2}$, which is set to $1.45 \times 10^{5}$; DNI is direct normal irradiance, $\mathrm{W} / \mathrm{m}^{2}$, which is set to 700 .

The energy balance and exergy balance can be expressed as:

$$
\begin{array}{r}
E_{\text {solar }}=E_{\text {hel }}+E_{\text {hel,loss }} \\
E_{\text {solar }}=E_{\text {hel }}+E_{\text {hel,loss }}
\end{array}
$$

Where, $\mathrm{E}_{\mathrm{hel}, \text { loss }}$ is the energy loss caused by the heliostat field, $\mathrm{MW}$; Ex $\mathrm{x}_{\text {solar }}$ is the exergy falling on the heliostats, MW; Ex $x_{\text {hel }}$ is the exergy reflected by the heliostats, MW; Ex $x_{\text {hel,loss }}$ is the exergy loss caused by the heliostat field, MW.

$\mathrm{Ex}_{\text {solar }}$ and $\mathrm{Ex}_{\text {hel }}$ can be obtained by:

$$
\mathrm{Ex}_{\text {solar }}=\mathrm{E}_{\text {solar }} \cdot\left(1-\mathrm{T}_{0} / \mathrm{T}_{\text {solar }}\right)
$$




$$
\mathrm{Ex}_{\text {hel }}=\mathrm{E}_{\text {hel }} \cdot\left(1-\mathrm{T}_{0} / \mathrm{T}_{\text {solar }}\right)
$$

Where, $\mathrm{T}_{\text {solar }}$ is the apparent sun temperature as an exergy source and taken to be $4500 \mathrm{~K}$ [32].

\subsubsection{Receiver model}

The receiver is located at the top of the solar tower. The working temperature of the molten salt used in this study can be suitable up to $600 \square[33]$, and, in this study, the temperature of molten salt out of the receiver is set at $580 \square$. The energy balance and exergy balance for the receiver are as follows:

$$
\begin{gathered}
\mathrm{E}_{\mathrm{rec}}=\mathrm{E}_{\mathrm{hel}}-\mathrm{E}_{\mathrm{rec}, \mathrm{loss}}=\mathrm{E}_{\mathrm{hel}} \cdot \eta_{\mathrm{rec}} \\
\mathrm{Ex}_{\mathrm{rec}}=\mathrm{Ex}_{\mathrm{hel}}-\mathrm{Ex}_{\mathrm{rec}, \mathrm{loss}}
\end{gathered}
$$

Where, $\mathrm{E}_{\mathrm{rec}}$ is energy absorbed by the molten salt in the receiver, MW; $\mathrm{E}_{\text {rec,loss }}$ is the energy loss in the receiver, MW; $\eta_{\text {rec }}$ is the receiver efficiency and is set to $89.16 \%$ [31]. Ex $x_{\text {rec }}$ is exergy absorbed by the molten salt in the receiver, MW; $\mathrm{Ex}_{\mathrm{rec}, \text { loss }}$ is the exergy loss in the receiver, MW. The useful energy and exergy absorbed by the molten salt can be calculated by:

$$
\begin{gathered}
\mathrm{E}_{\mathrm{rec}}=10^{-3} \mathrm{~m}_{\text {salt }}\left(\mathrm{h}_{\text {salt }, \text { out }}-\mathrm{h}_{\text {salt,in }}\right) \\
\mathrm{Ex}_{\mathrm{rec}}=10^{-3} \mathrm{~m}_{\text {salt }}\left(\mathrm{ex}_{\text {salt,out }}-\mathrm{ex}_{\text {salt,in }}\right)
\end{gathered}
$$

Where, $\mathrm{m}_{\text {salt }}$ is the mass flow rate of molten salt passing through the receiver, $\mathrm{kg} / \mathrm{s} ; \mathrm{h}_{\text {salt,in }}$ and $\mathrm{h}_{\text {salt,out }}$ are the specific enthalpy of molten salt in/out of the receiver, $\mathrm{kJ} / \mathrm{kg}$; ex $\mathrm{x}_{\text {salt,in }}$ and $\mathrm{ex}_{\text {salt,out }}$ are the specific exergy of molten salt in/out of the receiver, $\mathrm{kJ} / \mathrm{kg}$, which can be calculated by Eq. (6).

\subsubsection{Molten salt heat exchanger model}

In the molten salt heat exchanger, the temperature of steam/water will increase by absorbing the energy released by the molten salt. The energy balance and exergy balance of the molten salt heat exchanger can be expressed as:

$$
\mathrm{E}_{\mathrm{he}}=\mathrm{E}_{\mathrm{rec}}=10^{-3} \mathrm{~m}_{\mathrm{ms}}\left(\mathrm{h}_{\mathrm{ms}, \text { out }}-\mathrm{h}_{\mathrm{ms}, \text { in }}\right)
$$




$$
\mathrm{Ex}_{\mathrm{he}}=\mathrm{Ex}_{\mathrm{rec}}-\mathrm{Ex}_{\mathrm{he}, \mathrm{loss}}=10^{-3} \mathrm{~m}_{\mathrm{ms}}\left(\mathrm{ex}_{\mathrm{ms}, \mathrm{out}}-\mathrm{ex}_{\mathrm{ms}, \mathrm{in}}\right)
$$

Where, $E_{h e}$ is the energy released by the molten salt, MW; $m_{m s}$ is the mass flow rate of molten salt, $\mathrm{kg} / \mathrm{s} ; \mathrm{h}_{\mathrm{ms} \text {,in }}$ and $\mathrm{h}_{\mathrm{ms}, \text { out }}$ are the specific enthalpy of molten salt in/out of heat exchanger respectively, $\mathrm{kJ} / \mathrm{kg}$. Ex $\mathrm{he}_{\mathrm{he}}$ is the exergy released by the molten salt, MW; $\mathrm{Ex}_{\mathrm{he}, \mathrm{loss}}$ is the exergy loss in the heat exchanger, $\mathrm{MW} ; \mathrm{ex}_{\mathrm{ms} \text {,in }}$ and $\mathrm{ex}_{\mathrm{ms}, \text { out }}$ are the specific exergy of molten salt in/out of heat exchanger respectively, $\mathrm{kJ} / \mathrm{kg}$.

The energy and exergy absorbed by working fluid can be obtained by:

$$
\begin{gathered}
\mathrm{E}_{\mathrm{wf}}=\mathrm{E}_{\mathrm{he}}=10^{-3} \mathrm{~m}_{\mathrm{wf}}\left(\mathrm{h}_{\mathrm{wf}, \mathrm{out}}-\mathrm{h}_{\mathrm{wf}, \text { in }}\right) \\
\mathrm{Ex}_{\mathrm{wf}}=\mathrm{Ex}_{\mathrm{he}}=10^{-3} \mathrm{~m}_{\mathrm{wf}}\left[\left(\mathrm{h}_{\mathrm{wf}, \text { out }}-\mathrm{h}_{\mathrm{wf}, \text { in }}\right)-\mathrm{T}_{0}\left(\mathrm{~s}_{\mathrm{wf}, \mathrm{out}}-\mathrm{s}_{\mathrm{wf}, \text { in }}\right)\right]
\end{gathered}
$$

Where, $E_{w f}$ is the energy transferred to the working fluid, $\mathrm{MW} ; \mathrm{m}_{\mathrm{wf}}$ is the mass flow rate of working fluid, $\mathrm{kg} / \mathrm{s} ; \mathrm{h}_{\mathrm{wf}, \mathrm{in}}$ and $\mathrm{h}_{\mathrm{wf}, \text { out }}$ are the specific enthalpy of molten salt in/out of heat exchanger respectively, $\mathrm{kJ} / \mathrm{kg}$. Ex $\mathrm{wf}_{\mathrm{wf}}$ is the exergy transferred to the working fluid, MW; $\mathrm{s}_{\mathrm{wf}, \text { in }}$ and $\mathrm{s}_{\mathrm{wf}, \text { out }}$ are the specific entropy of molten salt in/out of heat exchanger respectively, $\mathrm{kJ} /(\mathrm{kg} \mathrm{K})$.

\subsubsection{Boiler model}

The boiler model is calculated based on the method that was proposed by the former Soviet Union in 1973 and was modified in China in 1998[34]. The logical flow diagram of this calculation is shown in Fig. 3 and the properties of the bituminous coal from Guizhou province are shown in Table 1.

In the furnace, radiative heat transfer is predominant and the heat transfer proportion by convection is very small. Therefore, the heat balance equation for the boiler is as follows:

$$
\mathrm{E}_{\mathrm{fur}}=10^{-3} \varphi \mathrm{B}_{\mathrm{j}} \mathrm{VC}\left(\mathrm{T}_{\mathrm{ad}}-\mathrm{T}_{\text {fur }, \text { out }}\right)=10^{-6} \mathrm{a}_{\mathrm{xt}} \mathrm{A}_{\mathrm{fur}} \sigma_{0}\left(\mathrm{~T}_{\text {hy }}^{4}-\mathrm{T}_{\mathrm{b}}^{4}\right)
$$

Where, $\mathrm{E}_{\mathrm{fur}}$ is the energy absorbed in the furnace, $\mathrm{MW} ; \varphi$ is the heat retention factor; $\mathrm{B}_{\mathrm{j}}$ is the calculated coal consumption rate, $\mathrm{kg} / \mathrm{s}$; VC is the mean net heat capacity rate of the combustion products 
per unit, $\mathrm{kJ} /(\mathrm{kg} \mathrm{K}) ; \mathrm{T}_{\mathrm{ad}}$ is the adiabatic flame temperature, $\mathrm{K} ; \mathrm{T}_{\text {fur,out }}$ is the temperature at the outlet of the furnace, $\mathrm{K} ; \mathrm{a}_{\mathrm{xt}}$ is the system emissivity; $\mathrm{A}_{\mathrm{fur}}$ is the furnace enclosure wall area, $\mathrm{m}^{2} ; \sigma_{0}$ is Stefan-Boltzmann constant, $5.67 \times 10^{-8} \mathrm{~W} /\left(\mathrm{m}^{2} \mathrm{~K}^{4}\right)$; $\mathrm{T}_{\text {hy }}$ and $\mathrm{T}_{\mathrm{b}}$ are the average temperatures of the flame and the furnace wall respectively, $\mathrm{K}$.

The convective heating surfaces refer to all the heating surfaces in the flue pass beyond the furnace outlet. The radiative heat transfer and convective heat transfer should be considered simultaneously. The heat balance equations for the convective heating surface are as follows:

$$
\mathrm{E}_{\mathrm{con}}=\frac{\mathrm{KH} \Delta \mathrm{t}}{\mathrm{B}_{\mathrm{j}}}
$$

For the gas side:

$$
\mathrm{E}_{\text {con }}=\varphi\left(\mathrm{h}_{\text {flue,in }}-\mathrm{h}_{\text {flue,out }}+\Delta \alpha \mathrm{h}_{\mathrm{air}}\right)
$$

For the working fluid side:

$$
E_{\text {con }}=\frac{m_{w f\left(h_{w f, o u t}-h_{w f, i n}\right)}}{B_{j}}-E_{r a d}
$$

Where, $\mathrm{E}_{\text {con }}$ is the convective heat transferred, $\mathrm{kJ} / \mathrm{kg} ; \mathrm{K}$ is the heat transfer coefficient; $\mathrm{H}$ is the area of heating surface, $\mathrm{m}^{2} ; \Delta \mathrm{t}$ is the logarithmic mean temperature difference, $\mathrm{K} ; \mathrm{h}_{\text {flue,in }}$ and $\mathrm{h}_{\text {flue,out }}$ are the specific enthalpy of flue gas in and out of the heater, $\mathrm{kJ} / \mathrm{kg} ; \Delta \alpha$ is the air leakage ratio; $\mathrm{h}_{\text {air }}$ is the specific enthalpy of cold air, $\mathrm{kJ} / \mathrm{kg} ; \mathrm{h}_{\mathrm{wf}, \text { in }}$ and $\mathrm{h}_{\mathrm{wf}, \text { out }}$ are the specific enthalpy of steam in and out of the heater respectively, $\mathrm{kJ} / \mathrm{kg}$; $\mathrm{E}_{\mathrm{rad}}$ is the radiative heat transferred, $\mathrm{kJ} / \mathrm{kg}$.

The energy absorbed in the boiler can be expressed as:

$$
\mathrm{E}_{\text {boiler }}=10^{-3}\left[\mathrm{~m}_{\mathrm{m}}\left(\mathrm{h}_{\mathrm{m}}-\mathrm{h}_{\mathrm{fw}}\right)+\mathrm{m}_{\mathrm{rh}}\left(\mathrm{h}_{\mathrm{rh}, \mathrm{out}}-\mathrm{h}_{\mathrm{rh}, \mathrm{in}}\right)\right]-\mathrm{E}_{\mathrm{wf}}
$$

Where, $\mathrm{E}_{\text {boiler }}$ is the thermal energy absorbed by working fluid in the boiler, $\mathrm{MW} ; \mathrm{m}_{\mathrm{m}}$ and $\mathrm{m}_{\mathrm{rh}}$ are the mass flow rate of the main and reheat steam, $\mathrm{kg} / \mathrm{s} ; \mathrm{h}_{\mathrm{m}}$ is the specific enthalpy of main steam, $\mathrm{kJ} / \mathrm{kg}$; $h_{f w}$ is the specific enthalpy of feed-water, $\mathrm{kJ} / \mathrm{kg} ; \mathrm{h}_{\mathrm{rh}, \text { in }}$ and $\mathrm{h}_{\mathrm{rh} \text {,out }}$ are the specific enthalpy of steam 
in/out of the re-heater respectively, $\mathrm{kJ} / \mathrm{kg}$;

Table 1. Properties of the coal

\begin{tabular}{lr}
\hline Items & Value \\
\hline Ultimate analysis $(\%)$ & 23.72 \\
Ash & 25 \\
Moisture & 57.5 \\
Carbon & 3.11 \\
Hydrogen & 0.99 \\
Nitrogen & 2 \\
Sulfur & 2.78 \\
Oxygen & 21981 \\
Low heating value (kJ/kg) & 22967 \\
Exergy (kJ/kg)
\end{tabular}




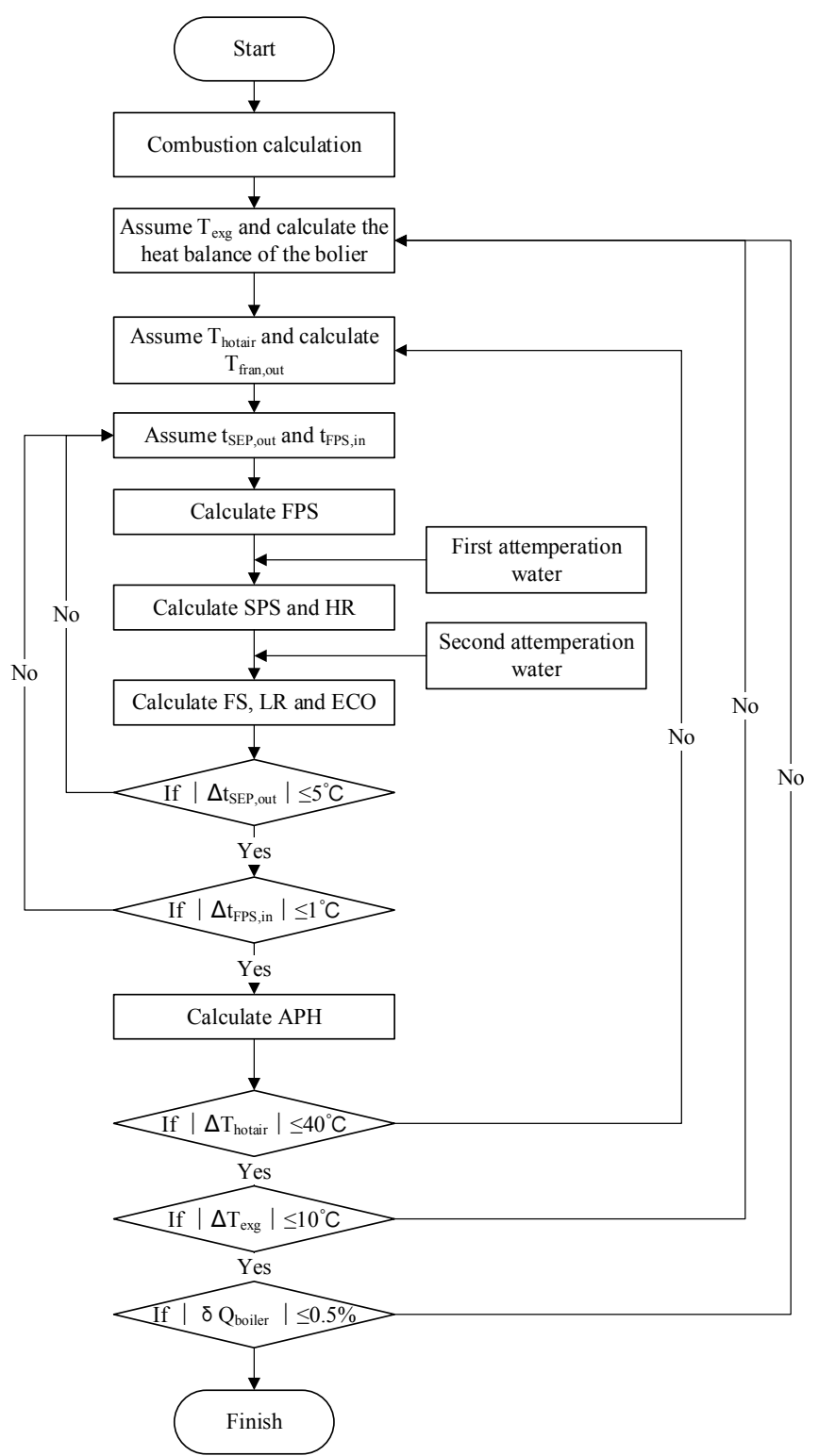

Fig.3 Calculation logic flow of boiler

Notes: $\mathrm{T}_{\text {exg }}$ : the temperature of the exit flue gas; $\mathrm{T}_{\text {hotair }}$ : the temperature of hot air; $\mathrm{t}_{\mathrm{SEP}, \text { out }}$ : the outlet temperature of SEP; $t_{F P S, i n}$ : the inlet temperature of FPS; $\Delta t_{S E P, o u t}$ : the temperature difference between the assumed and calculated outlet temperature of SEP; $\Delta t_{\mathrm{FPS}, \text { in }}$ : the temperature difference between the assumed and calculated inlet temperature of FPS; $\Delta \mathrm{T}_{\text {exg }}$ : the temperature difference between the assumed and calculated temperature of the exit flue gas; $\Delta \mathrm{T}_{\text {hotair }}$ : the temperature difference between the assumed and calculated temperature of hot air; $\delta \mathrm{Q}_{\text {boiler }}$ : the heat difference between the assumed and calculated $Q_{\text {boiler }}$ 


\subsubsection{Turbine and feed-water preheating system}

In this paper, the Matrix Thermal Balance Equation approach is used to calculate the turbine and feed-water preheating system, as shown in Eq. (26).

$$
\left[\begin{array}{llllllll}
\mathrm{q}_{1} & & & & & & & \\
\gamma_{2} & \mathrm{q}_{2} & & & & & & \\
\gamma_{3} & \gamma_{3} & \mathrm{q}_{3} & & & & & \\
\gamma_{4} & \gamma_{4} & \gamma_{4} & \mathrm{q}_{4} & & & & \\
\tau_{5} & \tau_{5} & \tau_{5} & \tau_{5} & \mathrm{q}_{5} & & & \\
\tau_{6} & \tau_{6} & \tau_{6} & \tau_{6} & \gamma_{6} & \mathrm{q}_{6} & & \\
\tau_{7} & \tau_{7} & \tau_{7} & \tau_{7} & \gamma_{7} & \gamma_{7} & \mathrm{q}_{7} & \\
\tau_{8} & \tau_{8} & \tau_{8} & \tau_{8} & \gamma_{8} & \gamma_{8} & \gamma_{8} & \mathrm{q}_{8}
\end{array}\right]\left[\begin{array}{l}
\mathrm{m}_{1} \\
\mathrm{~m}_{2} \\
\mathrm{~m}_{3} \\
\mathrm{~m}_{4} \\
\mathrm{~m}_{5} \\
\mathrm{~m}_{6} \\
\mathrm{~m}_{7} \\
\mathrm{~m}_{8}
\end{array}\right]=\mathrm{m}_{\mathrm{fw}}\left[\begin{array}{c}
\tau_{1} \\
\tau_{2} \\
\tau_{3} \\
\tau_{4} \\
\tau_{5} \\
\tau_{6} \\
\tau_{7} \\
\tau_{8}
\end{array}\right]
$$

Where, $\mathrm{m}_{\mathrm{fw}}$ is mass flow rate of feed-water from deareator, $\mathrm{kg} / \mathrm{s} ; \mathrm{m}_{\mathrm{i}}$ is mass flow rate of extraction steam in the $i_{\text {th }}$ stage, $\mathrm{kg} / \mathrm{s} ; \tau_{i}$ is the specific enthalpy change of feed-water in the $i_{\text {th }}$ heater, $\mathrm{kJ} / \mathrm{kg} ; \mathrm{q}_{\mathrm{i}}$ is specific enthalpy drop of extraction steam in $\mathrm{i}_{\text {th }}$ heater, $\mathrm{kJ} / \mathrm{kg} ; \gamma_{\mathrm{i}}$ is specific enthalpy drop of drain water in the $i_{\text {th }}$ heater, $\mathrm{kJ} / \mathrm{kg}$.

$q, \gamma, \tau$ can be obtained as follows:

$$
\begin{gathered}
\mathrm{q}_{\mathrm{i}}=\left\{\begin{array}{c}
\mathrm{h}_{\mathrm{i}}-\mathrm{h}_{\mathrm{d}, \mathrm{i}}(\mathrm{i}=1,2,3,5,6,7,8) \\
\mathrm{h}_{\mathrm{i}}-\mathrm{h}_{\mathrm{fw}, 5}(\mathrm{i}=4)
\end{array}\right. \\
\tau_{\mathrm{i}}=\mathrm{h}_{\mathrm{fw}, \mathrm{i}}-\mathrm{h}_{\mathrm{fw}, \mathrm{i}+1} \\
\gamma_{\mathrm{i}}=\left\{\begin{array}{c}
\mathrm{h}_{\mathrm{d}, \mathrm{i}-1}-\mathrm{h}_{\mathrm{d}, \mathrm{i}}(\mathrm{i}=2,3,6,7,8) \\
\mathrm{h}_{\mathrm{d}, 3}-\mathrm{h}_{\mathrm{fw}, 5}(\mathrm{i}=4)
\end{array}\right.
\end{gathered}
$$

Where, $h_{i}$ is the specific enthalpy of extraction steam for the $i_{t h}$ heater, $k J / k g ; h_{f w, i}$ is the specific enthalpy of feed-water at outlet for the $\mathrm{i}_{\mathrm{th}}$ heater, $\mathrm{kJ} / \mathrm{kg}$; $\mathrm{h}_{\mathrm{d}, \mathrm{i}}$ is the specific enthalpy of drain water in the $\mathrm{i}_{\text {th }}$ heater, $\mathrm{kJ} / \mathrm{kg}$.

In the power boosting operation mode of the STACP system, due to the introduction of solar energy, the mass flow rates of the main and reheat steam will inevitably be affected. Therefore, variable operating conditions should be taken into consideration. To simplify the calculation, the improved Flugel formula is employed in this paper, which is given as[29]:

$$
\frac{m_{i}}{m_{i, 0}}=\sqrt{\frac{p_{i}^{2}-p_{i+1}^{2}}{p_{i, 0}^{2}-p_{i+1,0}^{2}}}
$$


Where, $\mathrm{m}_{\mathrm{i}}$ is steam mass flow rate of the $\mathrm{i}_{\text {th }}$ stage of the turbine under off-design condition, $\mathrm{kg} / \mathrm{s} ; \mathrm{m}_{\mathrm{i}, 0}$ is steam mass flow rate of the $i_{\text {th }}$ stage of the turbine under original design condition, $\mathrm{kg} / \mathrm{s} ; \mathrm{p}_{\mathrm{i}}$ and $\mathrm{p}_{\mathrm{i}+1}$ are pressure of the $\mathrm{i}_{\text {th }}$ and $(\mathrm{i}+1)_{\text {th }}$ stage in turbine after the solar energy is introduced, $\mathrm{MPa} ; \mathrm{p}_{\mathrm{i}, 0}$ and $p_{i+1,0}$ are pressure of the $i_{\text {th }}$ and $(i+1)_{\text {th }}$ stage of the turbine of original coal-fired power generation unit, $\mathrm{MPa}$.

3.3 Thermal performance evaluation criteria

The thermal efficiency $\left(\eta_{\text {STACP }}\right)$ and exergy efficiency $\left(\varepsilon_{\text {STACP }}\right)$ are important parameters of the STACP system and can be expressed as:

$$
\begin{aligned}
\eta_{\text {STACP }} & =\frac{P}{E_{\text {coal }}+E_{\text {solar }}} \\
\varepsilon_{\text {STACP }} & =\frac{P}{E_{\text {coal }}+E_{\text {solar }}}
\end{aligned}
$$

Where, $\mathrm{P}$ is the net power output of the STACP system, MW; $\mathrm{E}_{\text {coal }}$ and $\mathrm{Ex}_{\text {coal }}$ are the thermal energy and exergy of the coal, MW.

The boiler's thermal efficiency $\left(\eta_{\text {boiler }}\right)$ and exergy efficiency $\left(\varepsilon_{\text {boiler }}\right)$ can be calculated as:

$$
\begin{aligned}
& \eta_{\text {boiler }}=\frac{E_{\text {boiler }}}{E_{\text {coal }}} \\
& \varepsilon_{\text {boiler }}=\frac{E_{\text {boiler }}}{E_{\text {coal }}}
\end{aligned}
$$

Where, Ex $x_{\text {boiler }}$ is the exergy of working fluid absorbed in the boiler, which can be calculated by Eq.

(6).

The standard coal consumption rate can be obtained by:

$$
\mathrm{b}_{\mathrm{s}}=\frac{3.6 \times 10^{6} \mathrm{E}_{\text {coal }}}{\mathrm{LHV}_{S} \mathrm{P}}
$$

Where, $b_{s}$ is the standard coal consumption rate, $g / k W h ; L_{S}$ is the low heating value of standard coal, which is $29271 \mathrm{~kJ} / \mathrm{kg}$.

The $\mathrm{CO}_{2}$ emissions can be calculated by: 


$$
\mathrm{Em}_{\mathrm{CO}_{2}}=\frac{3.6 \times 10^{6} \mathrm{~V}_{\mathrm{CO}_{2}} \rho_{\mathrm{CO}_{2}} \mathrm{E}_{\mathrm{coal}}}{\mathrm{LHV} \cdot \mathrm{P}}
$$

Where, $\mathrm{Em}_{\mathrm{CO}_{2}}$ is the $\mathrm{CO}_{2}$ emission, $\mathrm{g} / \mathrm{kWh} ; \mathrm{V}_{\mathrm{CO}_{2}}$ is the volume of $\mathrm{CO}_{2}$ for the combustion of $1 \mathrm{~kg}$ coal, $\mathrm{m}^{3} / \mathrm{kg}[34] ; \rho_{\mathrm{CO}_{2}}$ is the density of $\mathrm{CO}_{2}, \mathrm{~kg} / \mathrm{m}^{3} ; \mathrm{LHV}$ is the low heating value of the coal used in this study, $\mathrm{kJ} / \mathrm{kg}$.

\section{Case study}

4.1 Basic data and model validation

In this paper, a $600 \mathrm{MW}_{\mathrm{e}}$ coal-fired power plant in China is selected as the reference system and the boiler, turbine and preheating system models are coded in MATLAB. The design and simulation values of the boiler are shown in Table 2. The design and simulation values of the turbine and preheating system are listed in Table 3. From Table 2 and Table 3, a strong agreement can be seen between the simulation results and the design data, thus, the MATLAB developed model is shown to be reliable enough to use for further analysis.

Table 2. Comparison between simulation results and design data of boiler

\begin{tabular}{lcrrrrr}
\hline Parameter & Units & \multicolumn{5}{c}{ Steam/Water/Air } \\
& & \multicolumn{2}{c}{ Inlet } & \multicolumn{2}{c}{ Outlet } \\
& & design & simulation* & design & simulation* & Fluid type \\
\hline First Platen Super-heater & $\square$ & 428 & 429.5 & 470 & 470.5 & steam \\
Second Platen Super-heater & $\square$ & 460 & 461.6 & 512 & 509.6 & steam \\
High-temperature Re-heater & $\square$ & 468 & 469.5 & 567 & 567.0 & steam \\
Final Super-heater & $\square$ & 504 & 505.9 & 571 & 571.0 & steam \\
Low-temperature Re-heater & $\square$ & 300 & 300.0 & 468 & 469.5 & steam \\
Economizer & $\square$ & 274 & 274.0 & 329 & 330.9 & water \\
Air Heater & $\square$ & 25 & 25.0 & 325 & 323.0 & air \\
\hline
\end{tabular}

* The data are calculated without any solar energy input.

Table 3. Comparison between simulation results and design data of turbine and preheating system

\begin{tabular}{crrrrr}
\hline Parameter & Pressure $(\mathrm{MPa})$ & \multicolumn{2}{c}{ Enthalpy $(\mathrm{kJ} / \mathrm{kg})$} & \multicolumn{2}{c}{ Flow rate $(\mathrm{t} / \mathrm{h})$} \\
\cline { 3 - 6 } & & design & \multicolumn{1}{c}{ simulation* } & design & \multicolumn{1}{c}{ simulation* } \\
\hline Main steam & 24.2 & 3396 & 3398.8 & 1677.54 & 1677.54 \\
Cold reheat steam & 4.047 & 2970.1 & 2968.5 & 1400.30 & 1403.55 \\
Hot reheat steam & 3.642 & 3598.3 & 3600.0 & 1400.30 & 1403.55
\end{tabular}




\begin{tabular}{crrrrr} 
1st extraction & 5.977 & 3054.8 & 3051.8 & 104.23 & 105.59 \\
2nd extraction & 4.047 & 2970.1 & 2968.5 & 145.79 & 141.74 \\
3rd extraction & 1.774 & 3376.2 & 3376.5 & 60.88 & 62.00 \\
4th extraction & 0.9513 & 3189.1 & 3188.8 & 78.86 & 79.65 \\
5th extraction & 0.372 & 2974.9 & 2974.9 & 82.50 & 82.17 \\
6th extraction & 0.113 & 2733.8 & 2734.1 & 40.64 & 40.68 \\
7th extraction & 0.05577 & 2621.1 & 2621.1 & 54.61 & 54.68 \\
8th extraction & 0.0178 & 2493.7 & 2493.7 & 35.54 & 36.31 \\
Exhaust steam & 0.00588 & 2361.5 & 2361.5 & 973.83 & 975.24 \\
\hline
\end{tabular}

* The data are calculated without any solar energy input.

4.2 Results and discussion

Based on thermodynamic calculation of the boiler and solar field, the temperature ranges and flow rates of molten salt and steam/water are show in Table 4. In scheme 1, the temperature range of the extracted working fluid is from $428 \square$ to $566 \square$. In scheme 2, the temperature range of the extracted working fluid is from $331 \square$ to $566 \square$. In scheme 3, the temperature range of the extracted working fluid is from $331 \square$ to $566 \square$ for the evaporation/superheating part and from $303 \square$ to $566 \square$ for the reheating part.

Table 4. The operation details of three integration schemes

\begin{tabular}{lrrrrr}
\hline \multicolumn{1}{c}{ Items } & Units & Scheme 1 & Scheme 2 & \multicolumn{2}{c}{ Scheme 3 } \\
\hline Temperature range of molten salt & $\square$ & $460 \sim 580$ & $350 \sim 580$ & $350 \sim 580$ & $335 \sim 580$ \\
Temperature range of steam/water & $\square$ & $428 \sim 566$ & $331 \sim 566$ & $331 \sim 566$ & $303 \sim 566$ \\
mass flow rate of molten salt & $\mathrm{kg} / \mathrm{s}$ & 287.33 & 150.83 & 120.67 & 28.34 \\
mass flow rate of steam/water & $\mathrm{kg} / \mathrm{s}$ & 88.91 & 27.77 & 22.21 & 16.71 \\
\hline
\end{tabular}

Table 5 illustrates that, in fuel saving mode, FS2 has the lowest standard coal consumption rate $(261.28 \mathrm{~g} / \mathrm{kWh})$ with a decrease of $11.15 \mathrm{~g} / \mathrm{kWh}$ compared with coal-fired power system. The saving in the standard coal consumption rate of FS1 and FS3 are $10.97 \mathrm{~g} / \mathrm{kWh}$ and $10.91 \mathrm{~g} / \mathrm{kWh}$, respectively. In the power boosting mode, $\mathrm{PB} 2$ has the biggest power output $\left(625.5 \mathrm{MW}_{\mathrm{e}}\right)$. Therefore, the standard coal consumption rate of PB2 is lowest and declines about $11.11 \mathrm{~g} / \mathrm{kWh}$ compared with a standard coal-fired power system. From the standard coal consumption rate aspects, the fuel saving mode has demonstrated better performance than the power boosting mode. Due to the different coal consumption rates of these 
different schemes, the environmental performance, in terms of $\mathrm{CO}_{2}$ emissions, has similar characteristics to the standard coal consumption rate. $\mathrm{CO}_{2}$ emission of a coal-fired power system is $776.11 \mathrm{~g} / \mathrm{kWh}$. In fuel saving mode, FS2 has the lowest $\mathrm{CO}_{2}$ emission $(745.55 \mathrm{~g} / \mathrm{kWh})$ with a decrease of $30.56 \mathrm{~g} / \mathrm{kWh}$ compared with a conventional coal-fired power system. The reduced $\mathrm{CO}_{2}$ emissions of FS1 and FS3 are $30.05 \mathrm{~g} / \mathrm{kWh}$ and $29.88 \mathrm{~g} / \mathrm{kWh}$, respectively. In power boosting mode, the $\mathrm{CO}_{2}$ emission of $\mathrm{PB} 2$ is the lowest and declines by $30.45 \mathrm{~g} / \mathrm{kWh}$ in comparison with conventional coal-fired power system. The reduced $\mathrm{CO}_{2}$ emissions of PB1 and PB3 are $28.20 \mathrm{~g} / \mathrm{kWh}$ and $25.93 \mathrm{~g} / \mathrm{kWh}$, respectively. In addition, the solar share in fuel saving mode is about $7.30 \%$ while the power booting mode is only about $7.04 \%$, due to the larger share of power produced by the coal in the power boosting mode.

Table 5 also shows that the boiler's efficiencies in the STACP system are lower than those of a conventional coal-fired power system. This is because the boiler's working condition deviates from the design condition after the solar energy is introduced. In addition, for the same integration scheme, the boiler's efficiencies in fuel saving mode are higher than those in the power boosting mode. For fuel saving mode, FS2 has the highest energy efficiency and exergy efficiency. The energy efficiency and exergy efficiency of FS2 are $93.75 \%$ and $49.32 \%$, respectively. FS3 has the lowest energy efficiency and FS1 has the lowest exergy efficiency. Similar to the fuel saving mode, PB2 has the highest energy efficiency and exergy efficiency as well. PB3 has the lowest energy efficiency and PB1 has the lowest exergy efficiency.

In terms of solar field efficiency, for both fuel saving mode and power boosting mode, scheme 2 has the highest energy efficiency and scheme 1 has the highest exergy efficiency. The highest energy efficiencies of fuel saving and power bosting modes are $52.03 \%$ and $51.98 \%$, respectively. The highest exergy efficiencies of fuel saving and power bosting modes are $33.19 \%$ and $33.20 \%$, respectively. 
From system's efficiency point of view, Table 5 demonstrates that the system's efficiencies of STACP system are lower than those of coal-fired power plant. The reduction of the overall system efficiency is due to the introduction of the solar energy and its relative lower efficiency in comparison to boiler efficiency. For the fuel saving mode, FS2 has the highest energy efficiency and exergy efficiency. Compared with a coal-fired power system, the energy efficiency and exergy efficiency of FS2 decline $1.54 \%$ and $1.16 \%$, respectively. For the power boosting mode, PB2 has the highest energy and exergy efficiencies. Compared with a coal-fired power system, the energy and exergy efficiencies of PB2 decline $1.42 \%$ and $1.05 \%$, respectively. For schemes 1 and 2, power boosting mode has higher efficiencies than fuel saving mode. However, scheme 3 shows the opposite situation. Considering all of the above results, scheme 2 is the best integration scheme, this is because the heat exchange process in the furnace, which causes the biggest loss of all the heat exchange processes in the boiler, is partly replaced by heat exchange in the solar field.

Table 5. Thermal performance of STACP system

\begin{tabular}{llrrrrrrr}
\hline Items & Units & Coal-fired & \multicolumn{1}{l}{ FS1 } & FS2 & FS3 & PB1 & PB2 & PB3 \\
\hline Power output & $\mathrm{MW}$ & 600.96 & 600.96 & 600.96 & 600.96 & 623.61 & 625.50 & 622.73 \\
Standard coal consumption & $\mathrm{g} / \mathrm{kW}$ & 272.43 & 261.46 & 261.28 & 261.52 & 262.11 & 261.32 & 262.48 \\
rate & $\mathrm{h}$ & & & & & & & \\
& $\mathrm{g} / \mathrm{kW}$ & 776.11 & 746.05 & 745.55 & 746.23 & 747.91 & 745.66 & 750.17 \\
$\mathrm{CO}_{2}$ emissions & $\mathrm{h}$ & & & & & & & \\
Solar share & $\%$ & - & 7.30 & 7.30 & 7.30 & 7.04 & 7.04 & 7.04 \\
Boiler energy efficiency & $\%$ & 93.97 & 93.70 & 93.75 & 93.67 & 92.91 & 93.10 & 92.80 \\
Boiler exergy efficiency & $\%$ & 49.48 & 49.15 & 49.32 & 49.28 & 48.74 & 48.97 & 48.37 \\
Solar field energy & & & & & & & & \\
efficiency & $\%$ & - & 51.87 & 52.03 & 52.00 & 51.89 & 51.98 & 51.91 \\
Solar field exergy & & & & & & & & \\
efficiency & $\%$ & - & 33.19 & 31.23 & 31.13 & 33.20 & 31.25 & 31.09 \\
Energy efficiency & $\%$ & 44.56 & 42.99 & 43.02 & 42.99 & 43.01 & 43.14 & 42.95 \\
Exergy efficiency & $\%$ & 42.65 & 41.47 & 41.49 & 41.46 & 41.47 & 41.60 & 41.41 \\
\hline
\end{tabular}

4.3 Exergy analysis

Table 6. Exergy analysis of STACP system 


\begin{tabular}{llllllll}
\hline Items & \multicolumn{7}{c}{ Exergy (MW) } \\
& Coal-fired & FS1 & FS2 & FS3 & PB1 & PB2 & PB3 \\
\hline Exergy input & & & & & & & \\
Coal & 1409.03 & 1354.47 & 1353.55 & 1354.79 & 1409.03 & 1409.03 & 1409.03 \\
Solar & - & 94.72 & 94.72 & 94.72 & 94.72 & 94.72 & 94.72 \\
Sum & 1409.03 & 1449.19 & 1448.27 & 1449.51 & 1503.75 & 1503.75 & 1503.75 \\
Exergy destruction & & & & & & & \\
Boiler & 711.91 & 688.78 & 686.00 & 687.15 & 722.32 & 719.01 & 721.66 \\
Solar field & - & 63.29 & 65.14 & 65.23 & 63.28 & 65.12 & 65.30 \\
Steam turbine & 45.77 & 45.77 & 45.77 & 45.77 & 42.75 & 42.54 & 43.00 \\
Condenser & 23.71 & 23.72 & 23.71 & 23.71 & 24.25 & 24.29 & 24.21 \\
Feedwater heaters & 12.58 & 12.58 & 12.58 & 12.58 & 13.35 & 13.39 & 13.25 \\
Others & 14.10 & 14.10 & 14.11 & 14.11 & 14.20 & 13.91 & 13.59 \\
Sum & 808.08 & 848.24 & 847.31 & 848.55 & 880.14 & 878.26 & 881.02 \\
Exergy output & & & & & & & 6230 \\
Net power & 600.96 & 600.96 & 600.96 & 600.96 & 623.61 & 625.50 & 622.73 \\
\hline
\end{tabular}

Table 6 demonstrates the exergy destruction of key components. The same table shows that the exergy losses mainly occur in the boiler and solar field, about $88 \%$ of total exergy loss. For both two operation modes, scheme 1 has the highest boiler exergy loss and scheme 2 has the lowest boiler exergy loss. In terms of the solar field, for both operation modes, scheme 3 has the highest exergy loss and scheme 1 has the lowest exergy loss. This is because the temperature range of molten salt in scheme 1 is 460 580 $\square$, which is higher than that of scheme 3 (350 580 $\square$ and 335 580 $\square$ ). In order to further analyze exergy destruction of key components, a Sankey diagram is shown for a coal-fired power system, FS2 and PB2, seen Fig. 4. Fig. 4a shows that, the boiler has the maximum exergy loss $(50.52 \%)$ in the coal-fired power system, which means that about $88.09 \%$ of exergy destruction occurs in the boiler. In FS2, the proportion of solar exergy and coal exergy are $6.54 \%$ and $93.46 \%$, respectively, as energy sources of the STACP system. Only about $41.49 \%$ of exergy is converted into electricity, while about $58.51 \%$ of exergy is lost. The boiler has the maximum exergy destruction (686.0 MW), with the solar field being the next highest (65.1 MW). Exergy losses of the boiler and the solar field contribute about $88.65 \%$ of whole system's exergy loss. The exergy destruction rates of the turbine, condenser, feedwater 
and others are $5.4 \%, 2.8 \%, 1.5 \%$ and $1.7 \%$, respectively. In PB2, the proportion of solar exergy and coal exergy are $6.30 \%$ and $93.70 \%$, respectively, as energy sources of the STACP system. Only about $41.60 \%$ of exergy is converted into electricity, while about $58.40 \%$ of exergy is lost. The boiler has the maximum exergy destruction (719.0 MW), with the solar field being the next highest (65.1 MW). Exergy losses of the boiler and solar field contribute about $89.28 \%$ of whole system's exergy loss. The exergy destruction rates of turbine, condenser, feedwater and others are $4.8 \%, 2.8 \%, 1.5 \%$ and $1.6 \%$, respectively. It can be concluded that, for all the three systems, exergy loss mainly happens in the exergy input components because of the large temperature differences of heat exchange in the solar tower field and boiler.
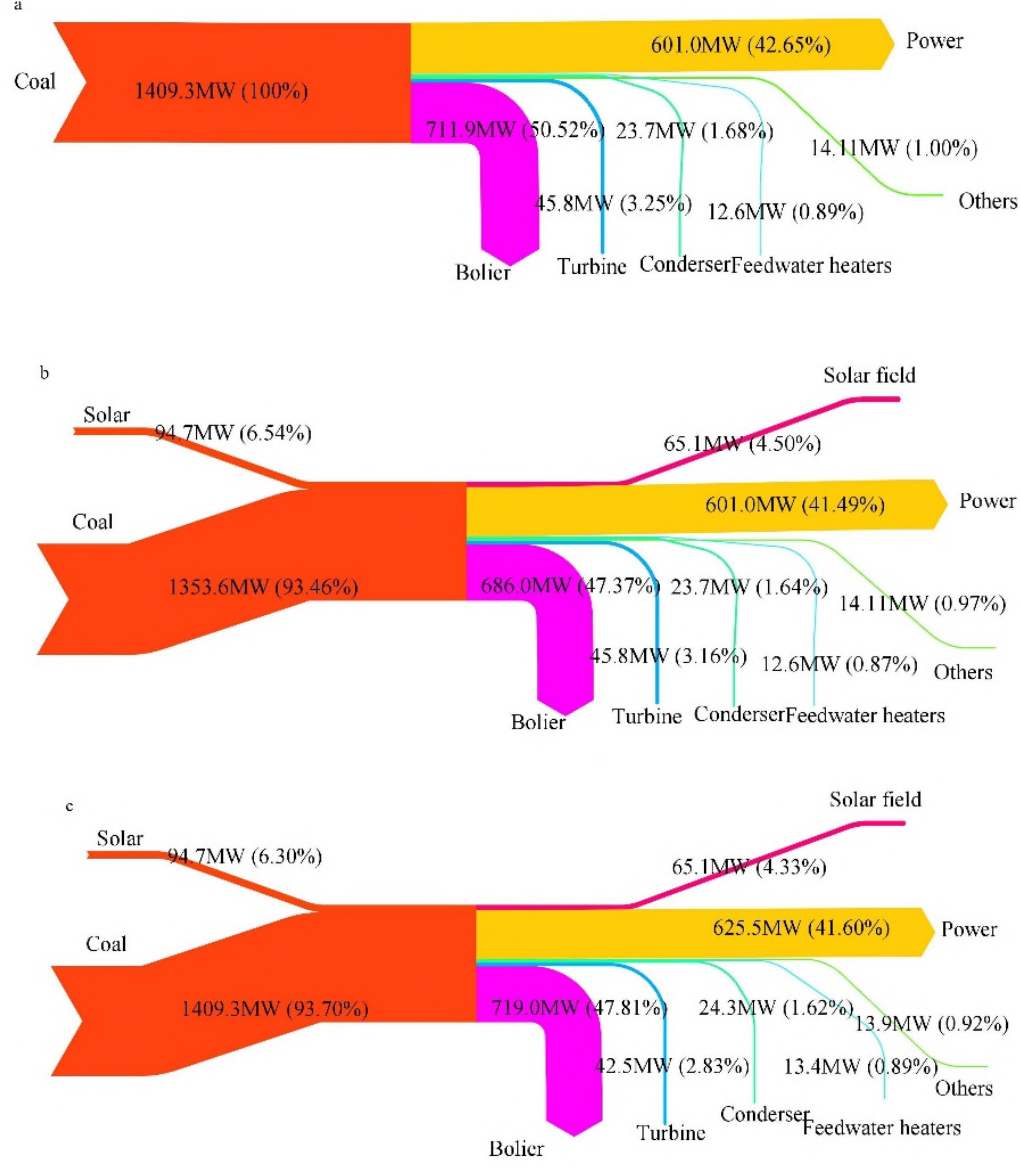

Fig. 4 Sankey diagrams of the (a) coal-fired power system, (b) FS2 and (c) PB2.

\section{Conclusions}

In this paper, three new integration schemes of STACP system are proposed. These three schemes 
in fuel saving and power boosting mode are analyzed based energy and exergy analysis. The following conclusions are derived from this study:

(1) The standard coal consumption rate and the efficiencies of boiler and system will decrease when solar energy is introduced into the boiler.

(2) The standard coal consumption rate of the fuel saving mode is lower than that of the power boosting mode for all three schemes. Compared with a coal-fired power system, the standard coal consumption rates of FS2 and PB2 decrease by $11.15 \mathrm{~g} / \mathrm{kWh}$ and $11.11 \mathrm{~g} / \mathrm{kWh}$, respectively.

(3) In fuel saving mode, FS2 has the lowest $\mathrm{CO}_{2}$ emission $(745.55 \mathrm{~g} / \mathrm{kWh})$ with a decrease of 30.56 $\mathrm{g} / \mathrm{kWh}$ in comparison with conventional coal-fired power system. In power boosting mode, the $\mathrm{CO}_{2}$ emission of PB2 is lowest and declines by $30.45 \mathrm{~g} / \mathrm{kWh}$ in comparison with conventional coal-fired power system.

(4) Considering both the standard coal consumption rate and efficiency, scheme 2 is the best suitable integration scheme.

(5) For STACP system, the boiler has the highest exergy loss and solar field has the second highest exergy loss. Exergy losses in the boiler and solar field contribute over $88 \%$ of whole system's exergy loss.

\section{Acknowledgments}

The research work is supported by National Major Fundamental Research Program of China (No. 2015CB251505), China National Natural Science Foundation (No. 51776063), the Fundamental Research Funds for the Central Universities (2016XS29, 2016YQ04) and China Scholarship Council.

\section{References}

[1] J. Li, X. Yu, J. Wang, S. Huang. Coupling performance analysis of a solar aided coal-fired power 
plant. Applied Thermal Engineering. 106 (2016) 613-24.

[2] C. Xu, P. Bai, T. Xin, Y. Hu, G. Xu, Y. Yang. A novel solar energy integrated low-rank coal fired power generation using coal pre-drying and an absorption heat pump. Applied Energy. 200 (2017) 170-

9.

[3] R.J. Zoschak, S.F. Wu. Studies of the direct input of solar energy to a fossil-fueled central station steam power plant. Solar Energy. 17 (1975) 297-305.

[4] J. Li, Z. Wu, K. Zeng, G. Flamant, A. Ding, J. Wang. Safety and efficiency assessment of a solaraided coal-fired power plant. Energy Conversion and Management. 150 (2017) 714-24.

[5] Y. Zhao, H. Hong, H. Jin. Optimization of the solar field size for the solar-coal hybrid system. Applied Energy. 185 (2017) 1162-72.

[6] J. Wu, H. Hou, Y. Yang. The optimization of integration modes in solar aided power generation (SAPG) system. Energy Conversion and Management. 126 (2016) 774-89.

[7] W. Junjie, H. Hongjuan, Y. Yongping. Research on the Performance of Coal-fired Power System Integrated with Solar Energy. Energy Procedia. 61 (2014) 791-4.

[8] Y. Zhao, H. Hong, H. Jin, P. Li. Thermodynamic mechanism for hybridization of moderatetemperature solar heat with conventional fossil-fired power plant. Energy. 133 (2017) 832-42.

[9] E. Hu, Y. Yang, A. Nishimura, F. Yilmaz, A. Kouzani. Solar thermal aided power generation. Applied Energy. 87 (2010) 2881-5.

[10] Y. Yang, Q. Yan, R. Zhai, A. Kouzani, E. Hu. An efficient way to use medium-or-low temperature solar heat for power generation - integration into conventional power plant. Applied Thermal Engineering. 31 (2011) 157-62.

[11] J. Qin, E. Hu, G.J. Nathan. The performance of a Solar Aided Power Generation plant with diverse 
“configuration-operation” combinations. Energy Conversion and Management. 124 (2016) 155-67.

[12] J. Qin, E. Hu, G.J. Nathan. Impact of the operation of non-displaced feedwater heaters on the performance of Solar Aided Power Generation plants. Energy Conversion and Management. 135 (2017) $1-8$.

[13] J. Qin, E. Hu, G.J. Nathan, L. Chen. Mixed mode operation for the Solar Aided Power Generation. Applied Thermal Engineering. (2018).

[14] H. Hong-juan, Y. Zhen-yue, Y. Yong-ping, C. Si, L. Na, W. Junjie. Performance evaluation of solar aided feedwater heating of coal-fired power generation (SAFHCPG) system under different operating conditions. Applied Energy. 112 (2013) 710-8.

[15] H. Hou, J. Wu, Y. Yang, E. Hu, S. Chen. Performance of a solar aided power plant in fuel saving mode. Applied Energy. 160 (2015) 873-81.

[16] C. Huang, H. Hou, E. Hu, M. Liang, Y. Yang. Impact of power station capacities and sizes of solar field on the performance of solar aided power generation. Energy. 139 (2017) 667-79.

[17] S. Adibhatla, S.C. Kaushik. Exergy and thermoeconomic analyses of 500 MWe sub critical thermal power plant with solar aided feed water heating. Applied Thermal Engineering. 123 (2017) 340-52.

[18] H. Hong, S. Peng, H. Zhang, J. Sun, H. Jin. Performance assessment of hybrid solar energy and coal-fired power plant based on feed-water preheating. Energy. 128 (2017) 830-8.

[19] J. Wu, H. Hou, Y. Yang. Annual economic performance of a solar-aided 600MW coal-fired power generation system under different tracking modes, aperture areas, and storage capacities. Applied Thermal Engineering. 104 (2016) 319-32.

[20] S. Adibhatla, S.C. Kaushik. Energy, exergy, economic and environmental (4E) analyses of a conceptual solar aided coal fired 500 MWe thermal power plant with thermal energy storage option. 
Sustainable Energy Technologies and Assessments. 21 (2017) 89-99.

[21] Y. Wang, J. Xu, Z. Chen, H. Cao, B. Zhang. Technical and economical optimization for a typical solar hybrid coal-fired power plant in China. Applied Thermal Engineering. 115 (2017) 549-57.

[22] R. Zhai, C. Li, Y. Chen, Y. Yang, K. Patchigolla, J.E. Oakey. Life cycle assessment of solar aided coal-fired power system with and without heat storage. Energy Conversion and Management. 111 (2016) 453-65.

[23] S. Peng, Z. Wang, H. Hong, D. Xu, H. Jin. Exergy evaluation of a typical 330MW solar-hybrid coalfired power plant in China. Energy Conversion and Management. 85 (2014) 848-55.

[24] R. Zhai, M. Zhao, K. Tan, Y. Yang. Optimizing operation of a solar-aided coal-fired power system based on the solar contribution evaluation method. Applied Energy. 146 (2015) 328-34.

[25] H. Hou, Z. Xu, Y. Yang. An evaluation method of solar contribution in a solar aided power generation (SAPG) system based on exergy analysis. Applied Energy. 182 (2016) 1-8.

[26] M. Zhang, X. Du, L. Pang, C. Xu, L. Yang. Performance of double source boiler with coal-fired and solar power tower heat for supercritical power generating unit. Energy. 104 (2016) 64-75.

[27] M. Zhang, C. Xu, X. Du, M. Amjad, D. Wen. Off-design performance of concentrated solar heat and coal double-source boiler power generation with thermocline energy storage. Applied Energy. 189 (2017) 697-710.

[28] Y. Zhu, R. Zhai, H. Peng, Y. Yang. Exergy destruction analysis of solar tower aided coal-fired power generation system using exergy and advanced exergetic methods. Applied Thermal Engineering. 108 (2016) 339-46.

[29] Y. Zhu, R. Zhai, J. Qi, Y. Yang, M.A. Reyes-Belmonte, M. Romero, et al. Annual performance of solar tower aided coal-fired power generation system. Energy. 119 (2017) 662-74. 
[30] C. Xu, Z. Wang, X. Li, F. Sun. Energy and exergy analysis of solar power tower plants. Applied Thermal Engineering. 31 (2011) 3904-13.

[31] F.J. Collado, J. Guallar. Two-stages optimised design of the collector field of solar power tower plants. Solar Energy. 135 (2016) 884-96.

[32] A. Bejan, D. Kearney, F. Kreith. Second law analysis and synthesis of solar collector systems. Journal of Solar Energy Engineering. 103 (1981) 23-8.

[33] B.-C. Du, Y.-L. He, Z.-J. Zheng, Z.-D. Cheng. Analysis of thermal stress and fatigue fracture for the solar tower molten salt receiver. Applied Thermal Engineering. 99 (2016) 741-50.

[34] D. Che. Boilers: theory, design and operation. Xi'an Jiaotong University Press2008. 